\title{
PENGARUH REWARD DAN INSENTIF TERHADAP KEPUASAN KERJA AGEN PLATINUM PT X JAKARTA

\author{
Denny Suriandhi
} \\ STIE Unisadhuguna Jakarta, Indonesia \\ Email: dennysndi88@gmail.com
}

\begin{abstract}
Abstrak
Pendahuluan : Keinginan perusahaan atas profesionalisme dan kinerja yang baik dari tenaga kerja erat kaitannya dengan bagaimana suatu perusahaan mampu memberikan penghargaan terhadap tenaga kerja.

Tujuan: Tujuan dari penelitian ini adalah untuk menganalisis pengaruh penghargaan dan insentif terhadap kepuasan agen platinum PT X wilayah DKI Jakarta.

Metode : Penelitian ini termasuk dalam kategori penelitian deskriptif kuantitatif. Penelitian ini menggunakan individu untuk unit analisis mereka, menjawab pertanyaan berdasarkan tanggapan dari individu yang termasuk dalam kategori agen platinum di wilayah DKI Jakarta. Jenis data yang digunakan adalah data utama. Populasi dalam penelitian ini adalah seluruh agen platinum di wilayah DKI Jakarta yang berjumlah sebanyak 20 orang, yang juga akan dijadikan sampel dengan teknik Purposive Sampling. Instrumen penelitian menggunakan kuesioner dengan skala Likert. Analisis data mencakup validasi dan uji keandalan. Analisis statistik menggunakan tes regresi linier ganda, koefisien uji penentuan, tes parsial (uji t), dan tes simultan (tes F).

Hasil : Hasil penelitian menunjukkan bahwa pengaruh hadiah sebagian untuk kepuasan platinum.

Kesimpulan : Secara parsial reward memengaruhi kepuasan kerja agen platinum PT X di wilayah DKI Jakarta terlihat dari uji t yang dilakukan.
\end{abstract}

Kata kunci : Reward; Insentif; Kepuasan Kerja; Agen Asuransi.

\section{Abstract}

Introduction: The company's desire for professionalism and good performance of the workforce is closely related to how a company is able to reward the workforce.

Objective: The purpose of this study was to analyze the effect of rewards and incentives on the satisfaction of PT X platinum agents in DKI Jakarta.

Method: This research falls into the category of quantitative descriptive research. The study used individuals for their analysis units, answering questions based on responses from individuals who fall into the platinum agent category in the DKI Jakarta area. The type of data used is the main data. The population in this study is all platinum agents in the DKI Jakarta area of 20 people, which will also be sampled with Purposive Sampling technique. The research instrument used questionnaires on the Likert scale. Data analysis includes validation and reliability tests. Statistical analysis uses multiple linear regression tests, determination test coefficients, partial tests ( $t$ tests), and simultaneous tests (F tests). 
Results: The results showed that the effect of rewards was partly for platinum satisfaction.

Conclusion: Partially the reward affects the job satisfaction of PT X platinum agent in the DKI Jakarta area as seen from the t test conducted.

Keywords: Reward; Incentive; Job Satisfaction; Insurance Agent.

\section{Pendahuluan}

Dewasa ini industri asuransi telah berkembang dengan pesat. Kegiatan perusahaan asuransi secara umum merupakan usaha yang berlandaskan pada kepercayaan masyarakat (Prabowo \& Jamal, 2017). Sehingga, profesionalisme dan kredibilitas perusahaan sangat dituntut agar dapat mencapai tujuan secara efektif dan efisien(Riniwati, 2016). Dalam membangun profesionalisme dan kredibilitas tersebut, dibutuhkan tenaga kerja yang kompeten. Keinginan perusahaan atas profesionalisme dan kinerja yang baik dari tenaga kerja erat kaitannya dengan bagaimana suatu perusahaan mampu memberikan penghargaan terhadap tenaga kerja (Sya'diyah \& Riduwan, 2015). Agen asuransi merupakan salah satu tenaga kerja suatu perusahaan asuransi sebagai tenaga penjual. Namun, agen asuransi tidak memiliki kontrak yang mengikat terhadap perusahaan asuransi, sehingga hak atau benefit yang didapat oleh seorang agen asuransi berbeda dengan karyawan perusahaan asuransi (Rachmawati, 2019). Sehingga, bentuk penghargaan seperti reward dan insentif yang diberikan oleh perusahaan asuransi memiliki peranan penting untuk memberikan kepuasan kerja guna meningkatkan produktivitas seorang agen asuransi (Kusuma, 2019).

Penelitian sebelumnya yang dilakukan oleh (Nurusshobakh, 2017) diuangkapakan bahwa da pengaruh reward terhadap kinerja karyawan Dapur Solo Kediri. Hal ini dibuktikan dari nilai t-hitung untuk $\mathrm{X} 2=3.148$ adalah lebih besar dari t-tabel 0,004. Diungkapkan pula pada penelitian (Koencoro, 2013) hasil yang didapat dari penelitian ini adalah variabe lReward Karyawan(X1), variabel Punishment Karyawan(X2) memiliki pengaruh secara bersama-sama terhadap variabel kinerja karyawan(Y). Penelitian lainnya yang ditulis oleh (Pramesti, Sambul, \& Rumawas, 2019) mengungkapkan bahwa reward dan punishment memiliki pengaruh terhadap kinerja pegawai. Penelitian yang saat ini dibuat merupakan studi lanjutan yang membahas terkait Pengaruh Reward dan Insentif Terhadap Kepuasan Kerja Agen Platinum di Wilayah DKI Jakarta

\section{Metode Penelitian}

Penelitian ini menggunakan metode deskriptif kuantitatifv (Rukajat, 2018), yang artinya menggambarkan proses dari mulai pengumpulan data, pengelompokan, tabulasi dan analisis hingga menginterprestasikannya (Zein et al., 2019). Penelitian ini akan melakukan survei dengan menggunakan alat kuesioner dengan skala likert sebagai instrument pengumpulan data, yang kemudian hasil data tersebut akan diolah dengan menggunakan software atau aplikasi SPSS versi 22 (Ghozali, 2018). 


\section{Hasil dan Pembahasan}

\section{A. Uji Validitas}

Sebuah alat ukur dikatakan valid apabila mampu mengukur apa yang diinginkan dan mengungkapkan data dari variabel yang diteliti secara tepat. Pengujian validitas dalam penelitian ini menggunakan analisis product momen correlation dari pearson. Variabel dinyatakan valid dapat diketahui dari signifikansi dari hasil perhitungan korelasi lebih kecil dari 0,05. Variabel juga dapat dinyatakan valid jika $r$ hitung positif, serta $r$ hitung $>r$ table (Yusup, 2018).

Tabel 1

Uji Validitas Variabel Reward (X1)

\begin{tabular}{cccc}
\hline Pernyataan & $\begin{array}{c}\text { Koefisien } \\
\text { Korelasi }\end{array}$ & Sig & Keterangan \\
\hline Butir 1 & 0,544 & 0,007 & Valid \\
\hline Butir 2 & 0,573 & 0,004 & Valid \\
\hline Butir 3 & 0,463 & 0,020 & Valid \\
\hline Butir 4 & 0,436 & 0,027 & Valid \\
\hline Butir 5 & 0,522 & 0,009 & Valid \\
\hline Butir 6 & 0,461 & 0,020 & Valid \\
\hline Butir 7 & 0,421 & 0,032 & Valid \\
\hline Butir 8 & 0,199 & 0,200 & Tidak Valid \\
\hline Butir 9 & 0,439 & 0,026 & Valid \\
\hline Butir 10 & 0,644 & 0,001 & Valid \\
\hline
\end{tabular}

Sumber: Hasil olah data menggunakan SPSS 22.0, 2017

Dari tabel diatas dapat diketahui bahwa untuk items pernyataan variabel reward yang tingkat signifikannya $<0,05$ dan tingkat korelasinya $>0,4$ dapat dinyatakan bahwa pernyataan butir pertama, kedua, ketiga, keempat, kelima, keenam, ketujuh, kesembilan, dan kesepuluh adalah valid. Sedangkan, pernyataan butir kedelapan dihilangkan karena tidak valid. Hal dikarenakan tingkat signifikannya $>0,05$ dan tingkat korelasinya $<0,4$, sehingga dinyatakan tidak valid (Ihsan, 2015).

\section{Tabel 2}

Uji Validitas Variabel Insentif $\left(\mathbf{X}_{2}\right)$

\begin{tabular}{cccc}
\hline Pernyataan & $\begin{array}{c}\text { Koefisien } \\
\text { Korelasi }\end{array}$ & Sig & Keterangan \\
\hline Butir 1 & 0,843 & 0,000 & Valid \\
\hline Butir 2 & 0,460 & 0,021 & Valid \\
\hline Butir 3 & 0,880 & 0,000 & Valid \\
\hline Butir 4 & 0,880 & 0,000 & Valid \\
\hline Butir 5 & 0,563 & 0,005 & Valid \\
\hline
\end{tabular}

Sumber: Hasil olah data menggunakan SPSS 22.0, 2017

Dari tabel diatas dapat diketahui bahwa untuk items pernyataan variabel insentif yang tingkat signifikannya $<0,05$ dan tingkat korelasinya $>0,4$ maka dapat dinyatakan bahwa secara keseluruhan items pernyataan tersebut adalah valid. 


\section{Tabel 3}

Uji Validitas Variabel Kepuasan Kerja Agen Platinum (Y)

\begin{tabular}{cccc}
\hline Pernyataan & $\begin{array}{c}\text { Koefisien } \\
\text { Korelasi }\end{array}$ & Sig & Keterangan \\
\hline Butir 1 & 0,836 & 0,000 & Valid \\
\hline Butir 2 & 0,770 & 0,000 & Valid \\
\hline Butir 3 & 0,747 & 0,000 & Valid \\
\hline Butir 4 & 0,638 & 0,001 & Valid \\
\hline Butir 5 & 0,708 & 0,000 & Valid \\
\hline
\end{tabular}

Sumber: Hasil olah data menggunakan SPSS 22.0, 2017

Dari tabel diatas dapat diketahui bahwa untuk items pernyataan variabel kepuasan kerja agen platinum yang tingkat signifikannya $<0,05$ dan tingkat korelasinya > 0,4 maka dapat dinyatakan bahwa secara keseluruhan items pernyataan tersebut adalah valid.

\section{B. Uji Reliabilitas}

Pengujian reliabilitas yang digunakan dalam penelitian ini adalah koefisien alfa atau cronbach's alpha. Items pengukuran dikatakan reliabel jika memiliki koefisien alfa lebih besar dari 0,6 (Validitas, 2013) Hasil pengujian reliabilitas terhadap variabel reward $\left(\mathrm{X}_{1}\right)$ dan insentif $\left(\mathrm{X}_{2}\right)$ terhadap kepuasan kerja agen platinum $(\mathrm{Y})$ dapat dilihat sebagai berikut:

\section{Tabel 4}

\section{Uji Reliabilitas}

\begin{tabular}{lccc}
\hline Variabel & $\begin{array}{c}\text { Cronbach's } \\
\text { Alpha }\end{array}$ & $\begin{array}{c}\text { Reliabilitas } \\
\text { Minimum }\end{array}$ & Keterangan \\
\hline Reward $\left(\mathrm{X}_{1}\right)$ & 0,644 & 0,600 & Reliabel \\
\hline Insentif $\left(\mathrm{X}_{2}\right)$ & 0,790 & 0,600 & Reliabel \\
\hline $\begin{array}{l}\text { Kepuasan Kerja } \\
\text { Agen Platinum }(\mathrm{Y})\end{array}$ & 0,791 & 0,600 & Reliabel \\
\hline
\end{tabular}

Sumber: Hasil olah data menggunakan SPSS 22.0, 2017

Dari hasil pengujian reliabilitas, dapat diperoleh hasil nilai koefisien alfa (Cronbach's Alpha) (Heo, Kim, \& Faith, 2015) untuk semua variabel adalah > 0,600. Sehingga dapat disimpulkan bahwa semua variabel telah reliabel.

\section{Uji Analisa Regresi Linear Berganda}

Untuk menguji pengaruh beberapa variabel bebas yang terdiri dari reward $\left(\mathrm{X}_{1}\right)$ dan insentif $\left(\mathrm{X}_{2}\right)$ terhadap variabel terikat yaitu variabel kepuasan kerja agen platinum (Y), maka digunakan analisis regresi linier dengan rumus sebagai berikut:

$$
\mathrm{Y}=\mathrm{a}+\mathrm{b}_{1} \cdot \mathrm{X}_{1}+\mathrm{b}_{2} \cdot \mathrm{X}_{2}+\mathrm{e}_{\mathrm{i}}
$$


Tabel 5

Uji Analisa Regresi Linear Berganda

Coefficients $^{\mathbf{a}}$

\begin{tabular}{|c|c|c|c|c|c|c|}
\hline \multirow{2}{*}{\multicolumn{2}{|c|}{ Model }} & \multicolumn{2}{|c|}{$\begin{array}{c}\text { Unstandardized } \\
\text { Coefficients }\end{array}$} & $\begin{array}{l}\text { Standardized } \\
\text { Coefficients }\end{array}$ & \multirow[b]{2}{*}{$\mathrm{t}$} & \multirow[b]{2}{*}{ Sig. } \\
\hline & & B & $\begin{array}{l}\text { Std. } \\
\text { Error }\end{array}$ & Beta & & \\
\hline \multirow[t]{3}{*}{1} & (Constant) & -.650 & 3.886 & & -.167 & .869 \\
\hline & Reward & .291 & .137 & .395 & 2.126 & .048 \\
\hline & Insentif & .461 & .177 & .484 & 2.609 & .018 \\
\hline
\end{tabular}

Sumber: Hasil olah data menggunakan SPSS 22.0, 2017

Berdasarkan dari perhitungan di atas maka diperoleh persamaan regresi sebagai berikut:

$$
\mathrm{Y}=-0,650+0,291 \mathrm{X} 1+0,461 \mathrm{X} 2+\mathrm{ei}
$$

Untuk lebih jelasnya adalah sebagai berikut:

1. Nilai Konstanta $=-0,650$

Nilai konstanta $-0,650$ menunjukkan bahwa apabila variabel $X_{1}$ dan $X_{2}$ dalam kondisi tetap atau konstan, maka kepuasan kerja agen platinum (Y) sebesar $-0,650$, yang berarti bahwa tanpa adanya variabel bebas yaitu reward $\left(\mathrm{X}_{1}\right)$ dan insentif $\left(\mathrm{X}_{2}\right)$ maka kepuasan kerja agen platinum $(\mathrm{Y})$ akan tetap -0,650, namun tanda negatif disini dapat menunjukkan akan mengurangi kepuasan kerja agen platinum.

2. Nilai b1 $=0,291$

Nilai b1 menunjukkan nilai 0,291dan memiliki tanda koefisien regresi yang positif, hal tersebut menunjukkan adanya pengaruh yang searah antara variabel reward $\left(\mathrm{X}_{1}\right)$ dengan variabel kepuasan kerja kerja agen platinum $(\mathrm{Y})$ yang artinya bahwa apabila terjadi peningkatan atau kenaikan pada variabel reward $\left(\mathrm{X}_{1}\right)$ dengan asumsi bahwa variabel insentif $\left(\mathrm{X}_{2}\right)$ dalam kondisi tetap atau konstan, maka kepuasan kerja agen platinum (Y) akan mengalami peningkatan dan sebaliknya.

3. Nilai $b 2=0,461$

Nilai b2 menunjukkan nilai 0,461 dan memiliki tanda koefisien regresi yang positif, hal tersebut menunjukkan adanya pengaruh yang searah antara variabel insentif (X2) dengan variabel kepuasan kerja agen platinum (Y) yang artinya bahwa apabila terjadi peningkatan atau kenaikan pada variabel insentif (X2) dengan asumsi bahwa variabel reward (X1) dalam kondisi tetap atau konstan, maka kepuasan kerja agen platinum (Y) akan mengalami peningkatan dan sebaliknya.

\section{Uji Koefisien Determinasi Berganda}

Koefisien determinasi digunakan untuk menghitung berapa besar sumbangan atau kontribusi variabel X1 dan X2 terhadap variabel $\mathrm{Y}$, atau dengan kata lain untuk menghitung besarnya pengaruh pemberian reward dan insentif terhadap kepuasan kerja agen platinum. Nilai koefisien determinasi dapat dilihat pada tabel dibawah ini: 


\section{Tabel 6}

Uji Koefisien Determinasi Berganda $\left(\mathbf{R}^{2}\right)$ Model Summary ${ }^{\text {b }}$

\begin{tabular}{|c|c|c|c|c|}
\hline Model & $\mathrm{R}$ & $\begin{array}{c}\mathrm{R} \\
\text { Square }\end{array}$ & $\begin{array}{c}\text { Adjusted R } \\
\text { Square }\end{array}$ & $\begin{array}{l}\text { Std. Error of } \\
\text { the Estimate }\end{array}$ \\
\hline 1 & $.784^{\mathrm{a}}$ & .614 & .569 & 1.24060 \\
\hline $\begin{array}{ll}\text { a. } & \text { Pred } \\
\text { b. } & \text { Dep }\end{array}$ & $\begin{array}{l}\text { rs: }(\mathrm{C} \\
\text { ent } \mathrm{Va}\end{array}$ & $\begin{array}{l}\operatorname{tant),}, \\
\text { ble: } Y\end{array}$ & & \\
\hline
\end{tabular}

Berdasarkan tabel 6, dapat diketahui korelasi antara variabel bebas dengan variabel terikat adalah kuat karena $\mathrm{R}=0,784>0,5$. Hal ini makin diperkuat dengan hasil dari R Square sebesar 0,614 yang berarti 61,4\% variasi kepuasan kerja agen platinum $(\mathrm{Y})$ disebabkan oleh faktor reward $\left(\mathrm{X}_{1}\right)$ dan insentif $\left(\mathrm{X}_{2}\right)$, sedangkan sisanya 38,6\% variasi kepuasan kerja agen platinum disebabkan oleh variabelvariabel lain yang tidak disertakan dalam penelitian ini.

\section{E. Uji Parsial (Uji t)}

Untuk mengetahui salah satu variabel bebas mempunyai pengaruh secara parsial terhadap variabel terikat, maka digunakan uji t.

\section{Tabel 7}

\section{Uji Parsial (Uji t)}

Coefficiants

\begin{tabular}{|c|c|c|c|c|c|c|c|c|}
\hline & \multirow[b]{3}{*}{ Model } & \multicolumn{2}{|c|}{$\begin{array}{c}\text { Unstandardized } \\
\text { Coefficients }\end{array}$} & \multirow{3}{*}{$\begin{array}{c}\text { Standardized } \\
\text { Coefficients } \\
\text { Beta } \\
\end{array}$} & \multirow[b]{3}{*}{$\mathbf{T}$} & \multirow[b]{3}{*}{ Sig. } & \multirow{2}{*}{\multicolumn{2}{|c|}{$\begin{array}{c}\text { Collinearity } \\
\text { Statistics } \\
\end{array}$}} \\
\hline & & \multirow[b]{2}{*}{ B } & \multirow{2}{*}{$\begin{array}{l}\text { Std. } \\
\text { Error }\end{array}$} & & & & & \\
\hline & & & & & & & Tolerance & VIF \\
\hline 1 & (Constant) & -.650 & 3.886 & & -.167 & .869 & & \\
\hline & Reward & .291 & .137 & .395 & 2.126 & .048 & .658 & 1.519 \\
\hline & Insentif & .461 & 177 & .484 & 2.609 & .018 & .658 & 1.519 \\
\hline
\end{tabular}

Sumber: Hasil olah data menggunakan SPSS 22.0, 2017

Dari tabel 7 dapat dijelaskan sebagai berikut:

1. Dengan membandingkan nilai $t_{\text {hitung }}$ dengan nilai $t_{\text {tabel. }}$. Hasilnya 2,126 $>2,10982$, maka variabel reward $\left(\mathrm{X}_{1}\right)$ mempunyai pengaruh yang signifikan terhadap variabel kepuasan kerja agen platinum (Y).

2. Dengan menggunakan angka probabilitas signifikansi 0,05 . Hasilnya $0,048<0,05$, maka variabel reward $\left(\mathrm{X}_{1}\right)$ mempunyai pengaruh yang signifikan terhadap variabel kepuasan kerja agen platinum (Y)

Berdasarkan tabel pengolahan data SPSS tersebut, diperoleh $t_{\text {hitung }}$ variabel insentif adalah 2,609 dengan tingkat signifikansinya 0,018. Selanjutnya membandingkan hasil $t_{\text {hitung }}$ dengan $t_{\text {tabel, }}$ yaitu 2,10982. Sehingga, hasil dari Uji $t$ tersebut adalah: 
1. Dengan membandingkan nilai $t_{\text {hitung }}$ dengan nilai $t_{\text {tabel. }}$. Hasilnya adalah 2,609 > 2,10982, maka variabel insentif $\left(\mathrm{X}_{2}\right)$ mempunyai pengaruh yang signifikan terhadap variabel kepuasan kerja agen platinum (Y).

2. Dengan menggunakan angka probabilitas signifikansi 0,05 . Hasilnya $0,018<$ 0,05 , maka variabel insentif $\left(\mathrm{X}_{2}\right)$ mempunyai pengaruh yang signifikan terhadap variabel kepuasan kerja agen platinum (Y).

\section{F. Uji Simultan (Uji F)}

Pembuktian hipotesis dalam penelitian ini dilakukan dengan menggunakan Uji $\mathrm{F}$ untuk menguji pengaruh secara simultan atau bersama-sama yaitu pengaruh variabel bebas yang terdiri dari reward $\left(\mathrm{X}_{1}\right)$ dan insentif $\left(\mathrm{X}_{2}\right)$ secara bersama sama (simultan) terhadap variabel kepuasan kerja agen platinum (Y), maka digunakan uji

F. Berikut adalah hasil uji $F$ yang dapat dilihat pada tabel berikut ini:

\begin{tabular}{|c|c|c|c|c|c|c|}
\hline \multicolumn{7}{|c|}{$\begin{array}{c}\text { Tabel } 8 \\
\text { Uji Simultan }(\text { Uji F) } \\
\text { ANOVA }^{\mathbf{A}}\end{array}$} \\
\hline & Model & $\begin{array}{l}\text { Sum of } \\
\text { Squares }\end{array}$ & df & $\begin{array}{c}\text { Mean } \\
\text { Square }\end{array}$ & $\mathbf{F}$ & Sig. \\
\hline \multirow[t]{3}{*}{1} & Regression & 41.635 & 2 & 20.818 & 13.526 & $.000^{\mathrm{b}}$ \\
\hline & Residual & 26.165 & 17 & 1.539 & & \\
\hline & Total & 67.800 & 19 & & & \\
\hline
\end{tabular}

a. Dependent Variable: Y

b. Predictors; (Constanta), x2. x1

Sumber: Hasil olah data menggunakan SPSS 22.0, 2017

Berdasarkan tabel di atas dapat diketahui bahwa nilai $F_{\text {hitung }}$ adalah sebesar 13,526 dengan taraf siginifikan sebesar 0,000. Selanjutnya, untuk sampel sebanyak 20 dan dua variabel bebas yang diteliti, maka dapat diketahui bahwa besarnya $F_{\text {tabel }}$ adalah sebesar 3,59. Maka untuk hasil dari Uji F adalah sebagai berikut:

1. Dengan membandingkan nilai $F_{\text {hitung }}$ dengan nilai $F_{\text {tabel }}$, yaitu $13,526>3,59$, maka terdapat pengaruh yang signifikan antara variabel reward $\left(\mathrm{X}_{1}\right)$ dan insentif $\left(\mathrm{X}_{2}\right)$ secara simultan terhadap variabel kepuasan kerja agen platinum (Y).

2. Dengan menggunakan angka probabilitas signifikansi 0,05 . Hasilnya $0,000<$ 0,05, maka dapat disimpulkan bahwa terdapat pengaruh yang signifikan antara variabel reward $\left(\mathrm{X}_{1}\right)$ dan insentif $\left(\mathrm{X}_{2}\right)$ secara simultan terhadap variabel kepuasan kerja agen platinum $(\mathrm{Y})$.

\section{Kesimpulan}

Berdasarkan penelitian yang berjudul Pengaruh Reward dan Insentif Terhadap Kepuasan Kerja Agen Platinum PT X di Wilayah DKI Jakarta, peneliti mencoba menarik kesimpulan yaitu secara parsial reward memengaruhi kepuasan kerja agen platinum PT X di wilayah DKI Jakarta terlihat dari uji t yang dilakukan. Secara parsial insentif memengaruhi kepuasan kerja agen platinum PT X di wilayah DKI Jakarta terlihat dari uji t yang dilakukan. Secara simultan reward dan insentif memengaruhi kepuasan kerja agen platinum PT X di wilayah DKI Jakarta terlihat dari hasil uji F yang dilakukan. 


\section{DAFTAR PUSTAKA}

Ghozali, Imam. (2018). Aplikasi analisis multivariate dengan program IBM SPSS 25.

Heo, Moonseong, Kim, Namhee, \& Faith, Myles S. (2015). Statistical power as a function of Cronbach alpha of instrument questionnaire items. BMC Medical Research Methodology, 15(1), 1-9.

Ihsan, Helli. (2015). Validitas Isi Alat Uukur Penelitian: Konsep Dan Panduan Penilaiannya. Pedagogia, 13(3), 173-179.

Koencoro, Galih Dwi. (2013). Pengaruh Reward dan Punishment Terhadap Kinerja (Survei Pada Karyawan PT. INKA (Persero) Madiun). Brawijaya University.

Kusuma, Devana Adila. (2019). Pengaruh Motivasi dan Kepuasan Kerja Terhadap Kinerja Agen Asuransi di PT. Prudential Life Assurance Ponorogo. IAIN Ponorogo.

Nurusshobakh, Azalia. (2017). Pengaruh Pemberian Insentif dan Reward Terhadap Kinerja Karyawan. (JMK) Jurnal Manajemen Dan Kewirausahaan, 2(3), 124-134.

Prabowo, Bagya Agung, \& Jamal, Jasri Bin. (2017). Peranan Dewan Pengawas Syariah terhadap Praktik Kepatuhan Syariah dalam Perbankan Syariah di Indonesia. Jurnal Hukum Ius Quia Iustum, 24(1), 113-129.

Pramesti, Rizki Ayu, Sambul, Sofia A. P., \& Rumawas, Wehelmina. (2019). Pengaruh reward dan punishment terhadap kinerja karyawan KFC Artha Gading. Jurnal Administrasi Bisnis (JAB), 9(1), 57-63.

Rachmawati, Putri. (2019). Pengaruh Reward Dan Motivasi Kerja Terhadap Kinerja Agen Asuransi Allianz Dalam Perspektif Ekonomi Islam (Studi Pada PT. Asuransi Allianz Life Indonesia Cabang Lampung). UIN Raden Intan Lampung.

Riniwati, Harsuko. (2016). Manajemen Sumberdaya Manusia: Aktivitas Utama dan Pengembangan SDM. Universitas Brawijaya Press.

Rukajat, Ajat. (2018). Pendekatan penelitian kuantitatif: quantitative research approach. Deepublish.

Sya'diyah, Chalimatus, \& Riduwan, Akhmad. (2015). Faktor-Faktor Yang Memengaruhi Perusahaan Melakukan Pergantian Auditor. Jurnal Ilmu Dan Riset Akuntansi (JIRA), 4(5).

Validitas, Uji. (2013). Reliabilitas. Hasil Uji Validitas Dan Reliabilitas Variabel X, 2.

Yusup, Febrinawati. (2018). Uji validitas dan reliabilitas instrumen penelitian kuantitatif. Tarbiyah: Jurnal Ilmiah Kependidikan, 7(1).

Zein, S. Zein, Yasyifa, L. Yasyifa, Ghozi, R. Ghozi, Harahap, Eerwin, Badruzzaman, F. H., \& Darmawan, Deni. (2019). Pengolahan dan Analisis Data Kuantitatif Menggunakan Aplikasi SPSS. Teknologi Pembelajaran, 4(2). 